\title{
Social inequality in environment of economic growth
}

\author{
Gotsulyak I.F. \\ Institute of Management, Economics and Finance \\ Kazan Federal University, \\ Kazan, 420008, Russia \\ Rudaleva I.A. \\ Institute of Management, Economics and Finance \\ Kazan Federal University, \\ Kazan, 420008, Russia
}

\begin{abstract}
The existence of socio-economic inequality predetermines the difference in household income. Despite the fact that differentiation of incomes generates a lot of negative phenomena (social instability, inefficient use of resources), it should be noted that moderate differentiation of incomes to certain limits is a positive factor of economic development, since it contributes to the growth of savings in certain population groups, invests in the economy of the country, revitalizing its investment activities. Moreover, income differentiation can act as an economic stimulus, forming a material interest in increasing the efficiency of labor and production, increasing skills, improving the personality. In a market economy, income received as a result of free competition is recognized as fair. At the same time, the market system does not provide an opportunity to obtain a decent income for the elderly, disabled people living in depressed areas or living in times of economic crisis. These people cannot be competitive economic agents. Nevertheless, the humanitarian principles that have become established in a civilized society require that everyone have an adequate minimum standard of living. Thus, the task of the state's social policy under conditions of economic growth is the elimination of those differentiation factors that generate excessive inequality. An important direction in resolving the problem of social inequality is the creation of a quality publicly accessible social infrastructure.
\end{abstract}

Keywords-social inequality, income differentiation, welfare level, social policy

\section{INTRODUCTION}

In modern studies, social inequality is defined as the unequal access of people to social, economic and other benefits, as well as the kind of social division in which individual members of society or groups are at different stages of the social ladder (hierarchy) and have unequal opportunities, rights and duties [1].

Social inequality is seen as a form of differentiation in which individual households, social groups, strata, classes are at different levels of the vertical social ladder and have unequal opportunities for satisfying their needs [2].

\author{
Ivanova N.V \\ Institute of Management, Economics and Finance \\ Kazan Federal University, \\ Kazan, 420008, Russia \\ Markova S.V. \\ Institute of Management, Economics and Finance \\ Kazan Federal University, \\ Kazan, 420008, Russia
}

The lack of a unified approach to explaining the origins of social inequality is due to the fact that it is perceived, on the one hand, as a perennial property of society, and, on the other hand, unjust unequal relations between people. As an integral feature of society, social inequality can carry a positive load as a source of social development, while the source of injustice creates social tension in society [3].

Thus, social inequality in society characterizes the uneven distribution of scarce resources of society (money, power, education, prestige) between different strata is the cause and the consequence of social stratification.

\section{PROBLEM STATEMENT}

Many factors affect social inequality: the culture of a given society, labor ethics, the social responsibility of the state, the development of industry, the development of monetary relations and financial institutions, etc. Despite the fact that differentiation of incomes generates a lot of negative phenomena (social instability, inefficient use of resources), it should be noted that moderate differentiation of incomes to certain limits is a positive factor of economic development, since it contributes to the growth of savings in certain population groups, invest in the economy of the country, revitalizing its investment activities [4]. Moreover, income differentiation can act as an economic stimulus, forming a material interest in increasing the efficiency of labor and production, increasing skills, improving the personality. Thus, the task of social policy is to eliminate those differentiation factors that generate excessive inequality.

In a market economy income received as a result of free competition is recognized as fair. At the same time, the market system does not provide an opportunity to obtain a decent income for the elderly, disabled people living in depressed areas or living in times of economic crisis. These people cannot be competitive economic agents. Nevertheless, the humanitarian principles that have become established in a civilized society require that everyone have an adequate minimum standard of living [5,9]. 
In the framework of a positive economic theory, an answer to the question of fair income distribution simply does not exist. The Pareto efficiency criterion cannot give us a theoretical basis for solving the problem of justice. It has been repeatedly noted that, as the market is a socially neutral mechanism, the impossibility of the income fair distribution is one of the market fiasco manifestations.

Primarily the social justice in economic theory is the problem of an acceptable income distribution inequality degree. And economists do not have a single answer to this. In the context of the well-known theory of welfare economics, a distribution corresponding to two conditions is justified: firstly, it must be equal, that is, none of the subjects of society prefers the commodity set of another person to its own commodity set; second, it must be Pareto efficient. At the same time, an equal, and Pareto-efficient distribution can be treated as fair [4].

\section{RESEARCH QUESTIONS}

Indicators characterizing inequality are monitored and evaluated in each society. This is done in order to determine whether the inequality degree does not exceed some allowable limits. The increase in the inequality degree is associated with the social inequalities that are taking place in society. The initial people inequality in terms of physical and intellectual data, purposefulness and motivation level allows one group to enter into unequal exchanges with other groups. Exceeding the permissible inequality degree leads to a large difference in the standard of living for different status groups in society, which can lead to increased social tensions in society and serve as a ground for the emergence, development and spread of social conflicts [10].

In general, the world economy tends to increase income inequality. In the second half of the twentieth century. Income inequality increased in 48 countries, including in the world's leading economies.

Over the past 16 years, the number of people who meet the requirements to be included in the world middle class (with net financial assets of 7-42 thousand euros) has doubled and amounted to about $20 \%$ of the world's population. At the end of 2016, approximately 540 million people worldwide attributed themselves to the world's rich with a net asset size of more than 42,000 euros. This is approximately 100 million more than in 2000. At the same time, the United States, Japan and Western Europe account for only $66 \%$ of households with a high level of welfare, compared with more than $90 \%$ in 2000 [6].

The increase of the middle class share in accumulated wealth reflects a property status inequality level reduction in the countries with a transitional market economy. First of all, the inequality grows in the industrially developed countries, as the $10 \%$ of the richest people share of wealth increases most. This can be partly explained by the fact that the global financial crisis has become the most painful for developed countries, especially in Europe [11]. The monetary policy aimed at stimulating growth, carried out by the central banks of developed countries after the crisis, exacerbated the situation, led to an increase in asset prices, primarily on bonds and securities held by the majority of households and caused damage to middle-class savings holders, which usually rely on low-activity savings instruments, such as bank deposits [7].

The problem of inequality is further complicated by differences in welfare indicators in individual countries, including countries with the same level of inequality. For example, in China, many poor are working thus, the social stratification indicators are very significant. According to estimates of the Institute of Population and Labor Economics of the Chinese Academy of Sciences, about 150 million Chinese live for $\$ 1 /$ day only, while there are about one million USD millionaires in the country [6]. The rural population and temporary workers (people from rural areas who come to the city for work) constitute the bulk of the working poor (about 200 million people) in the PRC. Yet, the abundance of the poor is not a brake, but an economic development engine in China. The opportunity to involve cheap labor resources from rural areas in production stimulates the economy.

\section{PURPOSE OF THE STUDY}

Economic growth in Russia after the crisis of 1998 was under conditions of a dynamic polarization of the population's incomes. In 2001, the incomes of $10 \%$ of the most well-off population of Russia exceeded the incomes of $10 \%$ of the poorest population more than 34 times. The 1998 crisis entailed a significant stratification of society, which in subsequent years was only consolidated. According to the annual study of the Credit Suisse Global Wealth Report (2013), the situation is worse than in Russia developed only in some small countries of the Caribbean [8].

For in-depth analysis of the dynamics of income differentiation, we used the results of regular statistical observations conducted by the Federal State Statistics Service (Rosstat) and the territorial agency Rosstat for the Republic of Tatarstan (Tatarstanstat). In all constituent entities of the Russian Federation, Rosstat conducts a selective survey of household budgets. The total sample size in Russia as a whole is 47.8 thousand households.

\section{RESEARCH METHODS}

The degree of income inequality in society is reflected through a number of indicators. The coefficients of population incomes differentiation determine the monetary incomes excess size of the high-income groups in comparison with the low-income population groups. The coefficient of funds (the median level) and the decile coefficient are used. The ratio of funds is the ratio between the average income of the compared groups or their shares in total income. The decile ratio shows the ratio between the average incomes of $10 \%$ of the wealthiest citizens and $10 \%$ of the poorest.

More clearly, the degree of income inequality reflects the Lorenz curve. It shows what proportion of the total income falls on a certain population group. Graphically, it lies between the lines that reflect absolute equality and absolute inequality. The higher the inequality of income distribution, the greater the curvature of the Lorenz curve. 
The Ginny index or the income concentration index is the ratio of the area between the real Lorentz curve and the straight line at $45^{\circ}$ to the area of the triangle below this line. The value of the Ginny index is between 0 and 1: the closer the Ginny index to 1 , the more unevenly the income is distributed.

\section{FINDINGS}

In the second half of the 1980s, by the level of income inequality, Russia was comparable to the Scandinavian countries. Since the beginning of the transition to a market economy, Russia has seen an unprecedented growth in income inequality in history. To date, Russia is on the same level of this indicator as Turkey and the countries of Latin America [11].

According to World Bank studies, inequality is becoming excessive, starting at a level of $30-40 \%$ for the Gini coefficient. Excessive inequality is called such inequality which causes negative social and economic consequences and becomes an insignificant brake in the development of the economy.

From 1990 to 2017, the Gini coefficient (income distribution by population group) increased from 0.24 to 0.377 , and the ratio of funds (the ratio of the richest $10 \%$ to the income of the poorest $10 \%$ of the population) in Russia from 1992 to 2017 it increased from 8 to 15.6 (taking into account the shadow capital it can be much higher). This is the US level of the early 20th century. According to experts, the ratio of funds in tsarist Russia was 6. In the USSR (as in today's Scandinavia), it was 3-4. That is, today in Russia, the gap between rich and poor is greater than in the prerevolutionary Russian Empire even according to the most conservative estimates $[4,8]$. Comparison of the Ginny index in Russia with other countries is presented in Table 1.

TABLE I. [GINNY INDEX IN DIFFERENT COUNTRIES]

\begin{tabular}{|l|c|}
\hline \multicolumn{1}{|c|}{ State } & Ginny index \\
\hline Russia Federation & 37,7 \\
\hline United States & 37,7 \\
\hline China & 42,2 \\
\hline Israel & 42,8 \\
\hline Brazil & 51,3 \\
\hline India & 35,1 \\
\hline Japan & 32,1 \\
\hline Finland & 26,8 \\
\hline
\end{tabular}

Even higher inequality rates are described by a number of countries in Africa and Latin America, for example, in South Africa, the Gini coefficient is $58 \%$, in Brazil - 51\%. In Argentina and Venezuela, the Gini coefficient is only slightly higher (45\%).

Despite the fact that unemployed and not working people are traditionally the most disadvantaged population categories throughout the world, in modern Russia a significant part of working citizens are poor. At the same time, the level of wages of working poor may not exceed the subsistence minimum per capita. So, in Russia there are still salaries in the amount of 5-6 thousand rubles, and they are paid to full-time employed, including those who have a certain qualification.

The least paid categories of working population include nannies and junior kindergarten teachers, librarians, museum workers, and junior medical personnel. At the same time, the availability of education and qualification of many of them does not allow to be attributed to the social lower classes of the population of the country, whereas they are on the verge of falling into the social stratum of the poor. Finally, the working poor can include specialists who suddenly left without work and who exist for unemployment benefits, which also has very modest dimensions in Russia. Finally, the working poor are those who can have good incomes, but the composition of the disabled family members makes them divide their incomes among all members of the family. Thus, in many cases, having many children is one of the most important reasons for Russian citizens to fall into the category of the poor [7].

The distribution of the population of Russia in terms of the average per capita monetary income is shown in Figure 1.

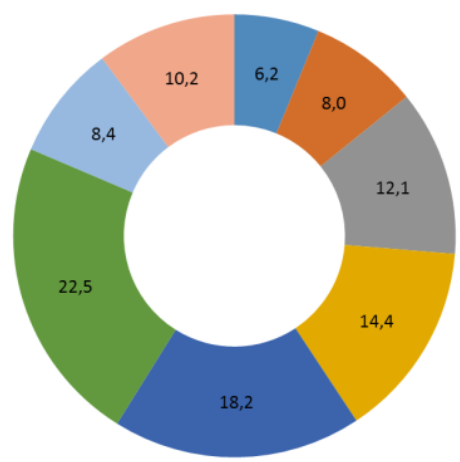

to $7 \mathrm{k}$

$=7-10 \mathrm{k}[$

$=10,1-14 \mathrm{k} \square$

$=14,1-19 \mathrm{k} \square$

- $19,1-27 \mathrm{k} \rrbracket$

$=27,1-45 \mathrm{k}[$

$\because 45,1-60 \mathrm{k} \square$

above $60 \mathrm{k}$ \

Fig. 1. [Distribution of the Russia Federation population by the average per capita monetary income in $2016, \%]$

In 2016, the structure of the population of Russia was dominated by citizens with income from 27.1 to 45 thousand rubles $(22.5 \%)$ and from 19.1 to 27 thousand rubles $(18.2 \%)$. Population with income over 60 thousand rubles per month in 2016 was $10.2 \%$ of the total population of Russia. At the same time, the share of the population with a per capita income per month of less than 7 thousand rubles is $6.2 \%$ and having income of 7 to 10 thousand rubles $-8 \%$ of the total population of the country. That is, we can talk about a rather high stratification of the population of Russia in terms of average per capita monetary income.

Most Russians are concerned about inequality in terms of well-being: almost $77 \%$ consider it painful for the whole society and $60 \%$ consider it personally. The second in the list of the most painful inequalities is inequality in access to "good" jobs. Over $40 \%$ of Russians consider it an acute problem for society, and more than a third face it personally. Inequality in access to education, as well as in "good" jobs, is more acutely perceived by young people, who are more often confronted with the impossibility to realize their life strategies in terms of education and work, which is connected among other things with the closure in recent years of "social elevators". 
The Russian population is least concerned with the disparity in leisure and vacation opportunities: only $8 \%$ recognize it as painful for themselves and $9 \%$ for society as a whole. First of all, the sensitivity to this problem depends on the availability of free time and the existing lifestyle.

Well-being, in the opinion of the majority of Russians (53\%), should result from a high level of education and qualification. But in reality, according to $47 \%$ of the population, well-being is facilitated by "the right connections" and a family in which the person was lucky (or unlucky) to be born, its well-being, the ability to provide the child with access to quality education and a sought-after profession. And only $20 \%$ of the population consider personal factors and hard work as factors of well-being. People with higher education, highly qualified specialists, managers of different levels and those whose households have incomes over the median level, more often believe that a prosperous life depends on the person himself and his personal efforts [5].

As for poverty, more often than not (76\%), Russians think that people are poor because of the situation at work (low wages, delay, unemployment). More than half see the causes of poverty in poor health, disability, harmful habits. Less than $30 \%$ believe that personal passivity of a person (laziness, unwillingness to change a habitual way of life) entails poverty, and only $20 \%$ consider it to be the reason for the low level of education and qualifications. Almost the same (19\%) part of the population is inclined to blame for poverty the lack of luck, and less than $15 \%$ believe that poverty is to blame for the family situation and social insecurity (inadequate social security and a large number of dependents). In general, in the views of Russians, the material position of a person in society depends more on external causes than on his own efforts.

\section{CONCLUSION}

A major factor in shaping social inequality in modern Russia is the regional factor. The bulk of the Russian poor live in rural areas and small "depressed" cities.

The transfer of "poverty" by inheritance is becoming increasingly familiar for modern Russia. So, at least half of all the modern Russian poor were born and brought up in poverty. Accordingly, they, more often than not, have neither the proper social capital, nor cultural capital, nor personal qualities and ideological guidelines that could allow them to escape from poverty. This category of the population becomes the carrier of the "culture of poverty", which is developing on the periphery of Russian society.

One of the most significant consequences of economic transformations in our country was the change in the pattern of income distribution among different categories of the population. The redistribution of state property, the emergence of the private sector, and the restructuring of the economy led to a reduction in subsidies for social purposes, increased differentiation of the population's income, accompanied by a large scale of impoverishment of people, an increase in the proportion of the poor in the total population.

On the other hand, the possession of cultural and social capital with a very high degree of probability guarantees a way out of poverty in the event of a sudden situational fall into the poor stratum (the latter can happen to non-poor people in case of their own business ruination, dismissal from work, problems with the law, etc.). The majority of those people who were not poor before, but accidentally fell into a state of poverty, sooner or later again leave the stratum of the poor and move to the more prosperous sectors of society, which is most often a number of resources of "inclusion" consequence from their own intellectual and professional potential and ending with the use social ties.

The problem of excessive inequality is closely related to the legitimacy of the inequality depth existing in the country in the eyes of the population. Separate studies show that the current inequality depth seems illegitimate to most of the Russians.

As for poverty assessments in Russia, they differ from each other. There are official Rosstat data, according to which in $2016,22.7$ million people (15.7\% of the total population of the country) have income below the subsistence level in Russia. At the same time, many experts consider the size of the subsistence minimum to be too low. According to the currently agreed definition of relative poverty of OECD and Eurostat, the poor are those who have income below $60 \%$ of the median income in the country. In 2015, the median income in Russia was 22.7 thousand rubles. If you apply the OECD and EU standards, then by these criteria, the poor in Russia is about $25 \%$ of the population.

\section{References}

[1] O.A. Ignatjeva, D.K. Rakhmatullina, E.R. Akhmetshina, Model of personal consumption under conditions of modern economy, Journal of Physics: Conference Series, 2017, Vol. 936, Is.1, Art. № 012066.

[2] T. Vakhitova, L. Gadelshina, The role and importance of the study of economic subjects in the implementation of the educational potential of education, Procedia-Social and Behavioral Sciences Journal, 2014.

[3] A.N. Mustafin, O.A. Ignatjeva, Features of russian economy in the context of innovative modernization and increasing role of human capital, Academy of strategic management journal, no. 15, 2016, pp. 27 38 .

[4] R.M. Kundakchyan, L.F. Garifova, Quality of Life as a Factor of SocioEcological and Economic Assessment, Mediterranean Journal of Social Sciences, Vol 5, No. 18, 2014.

[5] R.M. Kundakchyan, L.F. Garifova, Integral Estimate of SocioEcological-Economic Factors on the Quality of Life of Population of the Region, Mediterranean Journal of Social Sciences, Vol. 5, № 12, 2014.

[6] T. Vakhitova, L. Gadelshina, U. Saipullaev, A. Shikhalev, Foreign economic and interregional relations of the Russian Federation subjects (the case of The Tatarstan Republic): analysis and predictions, World Applied Sciences Journal, no. 27 (7), pp. 939-943, 2013.

[7] A.Y. Fairuzov, A.A. Smirnov, L.F. Zulfakarova, I.A. Rudaleva, Problems formation of personnel potential in the conditions innovative development, 4th international conference on education and social sciences (intcess 2017), 2017, Vol. 1, pp. 824-831.

[8] Credit Suisse Global Wealth Report, 2013. http://saejornal.ru/archives/512

[9] M.E. Nissen, A Multi-Agent Approach to Supply Chain Disintermediation, Proceedings of the 9th Annual Workshop on Information Technologies and Systems, 1999.

[10] M.H. Miller, K. Rock, Dividend Policy Under Asymmetric Information. The Journal of Finance, Reprint, 2007.

[11] I.A. Rudaleva, I.A. Kabasheva, A.G. Khairullina, Research of Organizational and Personal Factors of Professional Burnout of 
Personnel in a Consulting Organization, HELIX, 2018, Vol.8, Is.1, pp. 2372-2376. 